\title{
Masticatory Changes as a Result of Oral Disorders in Smokers
}

\author{
Rafaela Soares Rech ${ }^{1}$ Karoline Weber dos Santos ${ }^{1}$ Marcia Angelica Peters Maahs ${ }^{1}$ \\ Deisi Cristina Gollo Marques Vidor ${ }^{1}$
}

${ }^{1}$ Department of Fonoaudiologia, Universidade Federal de Ciências da Saúde de Porto Alegre, Porto Alegre, Brazil

Int Arch Otorhinolaryngol 2014;18:369-375.

\begin{abstract}
Address for correspondence Rafaela Soares Rech, Student, Department of Fonoaudiologia, Universidade Federal de Ciências da Saúde Porto Alegre, Rua Dinazaíde Ferreira de Andrade, 129, Caxias do Sul, 95057-340, Brazil (e-mail: rafasoaresrech@hotmail.com).
\end{abstract}

\begin{abstract}
Introduction For chewing to occur properly, it is necessary that all oral structures are present and of normal standard.

Objectives The aim of this study is to verify the presence of oral changes in smokers and the impact of the changes on masticatory function compared with individuals who never smoked.

Methods Forty-eight subjects were evaluated, split into two study groups (24 subjects each) of current tobacco users and individuals who have never smoked. The variables halitosis, presence of lesions suggestive of caries and periodontal problems, number of teeth, classification of malocclusions according to angle, standard grinding food, chewing pattern, and speed of chewing were evaluated.

Results There was no statistically significant difference in tooth loss between the groups, but the smokers had more losses manifesting malocclusion. Most smokers had halitosis and lesions suggestive of caries and periodontal problems; the halitosis was

\section{Keywords}

- mastication

- malocclusion

- halitosis

- smoking

- stomatognathic system associated with the latter variable. Masticatory speed was also reduced significantly in these individuals compared with the control group when associated with occlusal alterations, in addition to grinding food with the tongue. No difference was observed regarding the chewing pattern. The presence of halitosis and periodontal problems were more common in those who smoke more than 20 years.

Conclusion There is an association between smoking and dental changes, which cause increased masticatory changes.
\end{abstract}

\section{Introduction}

The human dentition has biological and nonbiological functions and plays a vital role in the daily life of all individuals. The dental structure it is important for the overall appearance of the face, chewing, and speech. ${ }^{1}$ In adults, each dental arch has a total of 16 permanent teeth, which are composed of connective tissue, blood vessels, nerves, and inorganic materials. Each arch has 4 incisors, 2 canines, 2 premolars, 2 molars, and a third molar, which may be congenitally absent. Each tooth has a specific function; the incisors bite or cut food; the canines break and shatter substances; the molars crush and grind food during chewing. ${ }^{2}$ Each set of teeth is responsible for one-step preparation of the bolus that will result in a pattern of chewing and swallowing; therefore, the dental arch is considered one of the precursors of the digestive process. ${ }^{3}$

Besides the presence of all the teeth in the oral cavity, it is essential that the contact between the dental arches occurs harmoniously, allowing better functionality during the chewing process. This is more common in Angle class I, when there are no associated dental problems. For classification received

February 4, 2014

accepted

June 9, 2014

published online

August 13, 2014
DOI http://dx.doi.org/

10.1055/s-0034-1385843. ISSN 1809-9777.
Copyright (c) 2014 by Thieme Publicações License terms Ltda, Rio de Janeiro, Brazil

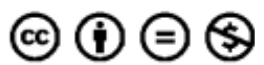


purposes, Angle divided the malocclusions into classes I, II, and III, clinically evaluating the relationship of the upper to lower first permanent molar. In class I malocclusion, the mesiobuccal cusp of the upper first permanent molar should be embodied in the mesiobuccal groove of the lower first permanent molar, a normal relationship between the maxilla and mandible in the anterior-posterior direction. In class II malocclusion, the mesiobuccal of the first permanent molar groove should be structured after the mesiobuccal cusp of the upper first permanent molar, a distal relationship of the mandible relative to the maxilla. It can be subdivided into division 1, distoclusion in which the upper incisors are extreme inclined to buccal face, and division 2, distoclusion in which the central incisors are almost normal or inclined to the palatal face, and the lateral incisors are inclined to the buccal face or mesial face, with subdivisions when distoclusion occurs only on one side, right or left, in the dental arch. In class III malocclusion, the mesiobuccal of the lower first permanent molar groove should be articulated before the mesiobuccal cusp of the upper first permanent molar, reflecting a mesial ratio of the mandible relative to the maxilla. This may also have subdivisions when only one side, right or left, of the dental arch has malocclusion. According to Angle, classes II and III may be due to changes in the arrangement of teeth in the oral cavity and not necessarily skeletal problems. To confirm the skeletal pattern, cephalometric analysis is necessary. $^{4}$

When there is an imbalance of these structures, the force is distributed on a much smaller area, causing change in occlusal contact in the positioning of the mandible and maxilla. These errors generate associated facial problems and promote imbalance in dentition and the facial skeleton, thus compromising the oral functions such as mastication. ${ }^{3}$

Chewing is one of the vital functions of the stomatognathic system and depends on the participation of teeth to prepare the food, cutting it, grinding it, and crushing it properly. When there is a change in the arrangement of teeth in the oral cavity or tooth loss, the individual may have inefficient chewing. The loss of any tooth tends to promote an imbalance in occlusal relationships between the remaining teeth, causing adverse effects on the functions of the oral cavity. ${ }^{5}$ Besides tooth loss, there is a relationship with the distribution of teeth present: if tooth loss occurs in the posterior region, the impact on this function will be greater, because the teeth in this region grind the food, which is essential for effective mastication. $^{1}$

The changes caused in the oral structure and function due to tooth loss and/or malocclusion can result from intrinsic factors, such as those arising from a specific genetic pattern, or from extrinsic factors. One of these factors commonly associated with tooth loss and other oral changes is tobacco. ${ }^{6}$ Smoking is a harmful oral habit that has increased worldwide in recent decades, causing higher incidence of cancers of the mouth and pharynx. ${ }^{7,8}$

Constant exposure to chemicals in tobacco damages the oral tissue, promoting an increase in epithelial renewal. However, cell renewal does not take place efficiently, because the oral cavity cells originating from this biological mecha- nism have cytologic changes caused by the same effect of chemical agents that triggered the process. $^{9}$ Among the manifestations that we can find under that process, there are numerous injuries that affect the lips, including those caused by chronic irritation. In cytologic research, it was demonstrated that the mucosa in the edge of the tongue suffers a greater keratinization when exposed to smoke. ${ }^{10 .}$ Moreover, methods for observing cytology of the oral cavity showed an increased frequency of micronuclei formation in individuals exposed to tobacco. ${ }^{10}$ All these situations can lead to periodontal disease, due to increased gingival inflammation, causing bone loss and tooth loss. ${ }^{9-11}$

Based on the data reported, the aim of this study is to verify and compare the presence of tooth loss and oral alterations in smokers compared with nonsmokers and the impact of these changes in masticatory function.

\section{Methods}

This study presented a descriptive and comparative prospective cross-sectional design, which was approved by the Ethics Committee in Research under protocol 3636/11. Survey participants agreed to undertake the proposed evaluations after explanation of the objectives and procedures of the study and after they signed an informed consent form. The study sample consisted of 48 subjects classified in two groups: current tobacco users and individuals who had never smoked and who were not exposed to passive consumption of the substance. For the group of smokers, patients from the pulmonology clinic were invited to participate. The group of nonsmokers included individuals who volunteered to participate in the study after disclosure.

For better distribution of the sample, the study groups were paired regarding gender and age. Four age groups were used: 18 to 25,26 to 40,41 to 60 , and 61 and older. In each age group, six subjects (three women and three men) were evaluated in each study group.

Regarding the inclusion criteria of subjects in the study, participants were more than 18 years old; healthy; without neurodegenerative, systemic, salivary, or orofacial anatomy disease; with no changes in the upper airways; in no use of medication, odontologic treatment, and speech therapy at the time of evaluation.

To characterize the teeth of individuals and to establish the relationship of dental and occlusal characteristic changes in the subjects evaluated, two evaluations were proposed: analysis of the oral cavity and teeth and characterization of chewing patterns in both study groups.

In the evaluation of the aspects related to oral cavity, the presence of halitosis; lesions suggestive of caries; observation of periodontal problems, characterized by gingival retraction and hyperemia; analysis of the number of teeth, which were excluded in individuals with tooth agenesis; and classification of malocclusion according to Angle were evaluated.

Besides the analysis of the dentition, an evaluation of mastication was performed using bread, noting food crushing pattern, classified as to the realization with posterior, anterior teeth or crushing with the tongue; chewing pattern, classified 
Table 1 Comparison between the groups regarding the oral and masticatory characteristics

\begin{tabular}{|c|c|c|c|c|c|c|}
\hline \multirow[t]{3}{*}{ Variable } & \multirow[t]{3}{*}{ Category } & \multicolumn{4}{|c|}{ Group } & \multirow[t]{3}{*}{$p$} \\
\hline & & \multicolumn{2}{|c|}{ Nonsmokers } & \multicolumn{2}{|c|}{ Smokers } & \\
\hline & & $n$ & $\%$ & $n$ & $\%$ & \\
\hline \multirow[t]{2}{*}{ Halitosis } & No & 23 & 95.8 & 16 & 66.7 & $0.023^{a}$ \\
\hline & Yes & 1 & 4.2 & 8 & 33.3 & \\
\hline \multirow[t]{2}{*}{ Lesions suggestive of cavities } & No & 23 & 95.8 & 17 & 70.8 & $0.048^{a}$ \\
\hline & Yes & 1 & 4.2 & 7 & 29.2 & \\
\hline \multirow[t]{2}{*}{ Periodontal problems } & No & 20 & 83.3 & 11 & 45.8 & $0.015^{\mathrm{a}}$ \\
\hline & Yes & 4 & 16.7 & 13 & 54.2 & \\
\hline \multirow[t]{4}{*}{ Class left } & Class I & 19 & 79.2 & 16 & 66.7 & $0.039^{a}$ \\
\hline & Class III & - & - & 4 & 16.7 & \\
\hline & Class II/I & 5 & 20.8 & 2 & 8.3 & \\
\hline & Class II/II & - & - & 2 & 8.3 & \\
\hline \multirow[t]{4}{*}{ Class right } & Class I & 17 & 70.8 & 12 & 50.0 & $0.006^{\mathrm{a}}$ \\
\hline & Class III & - & - & 5 & 20.8 & \\
\hline & Class II/I & 7 & 29.2 & 3 & 12.5 & \\
\hline & Class II/II & - & - & 4 & 16.7 & \\
\hline \multirow[t]{3}{*}{ Crushing food } & Posterior teeth & 22 & 91.7 & 13 & 54.2 & $0.011^{\mathrm{a}}$ \\
\hline & Anterior teeth & 2 & 8.3 & 7 & 29.2 & \\
\hline & With tongue & - & - & 4 & 16.7 & \\
\hline \multirow[t]{3}{*}{ Chewing speed } & Adequate & 16 & 66.7 & 13 & 54.2 & $0.048^{a}$ \\
\hline & Increased & 5 & 20.8 & 1 & 4.2 & \\
\hline & Decreased & 3 & 12.5 & 10 & 41.7 & \\
\hline \multirow[t]{4}{*}{ Chewing pattern } & Bilateral alternating & 15 & 62.5 & 9 & 37.5 & 0.287 (NS) \\
\hline & Unilateral right & 5 & 20.8 & 6 & 25.0 & \\
\hline & Unilateral left & 1 & 4.2 & 4 & 16.7 & \\
\hline & Simultaneous bilateral & 3 & 12.5 & 5 & 20.8 & \\
\hline
\end{tabular}

Abbreviation: NS, not significant.

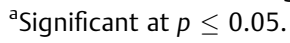

as to the laterality of the bolus; and chewing speed, classified as adequate, increased, or decreased.

The collected data were analyzed using tables, descriptive statistics, and statistical tests. Fisher exact test was used for comparison between groups regarding oral masticatory features and for the relationship between the presence of halitosis and oral changes in smokers, and class occlusal and masticatory characteristics of smokers. For a quantitative analysis of the number of teeth, we used the Student $t$ test, and for the relationship between the total number of teeth and grinding standard of food for smokers, we used the analysis of variance (ANOVA). Results were considered significant at a level of $5 \%$, and the statistical software used for data analysis was SPSS version 20.0.

\section{Results}

Through Fisher exact test, the presence of halitosis, lesions suggestive of caries, and periodontal problems were found to be significantly higher for the group of smokers compared with the control group, as shown in - Table 1. Regarding the Angle classification, smokers showed significant differences compared with the control group for the appearance of class III pattern on the left side and class III and class II subdivision II on the right side. In a quantitative analysis of the total number of teeth of the right, left, and both sides, there was no difference between groups according to the Student $t$ test $(p>0.05)$, although smokers had fewer teeth compared with nonsmokers.

- Table 1 also shows that nonsmokers showed a food crushing pattern with the posterior teeth, and the smokers performed this procedure with the tongue, a significant difference by Fisher exact test compared with the control group. Chewing speed was significantly lower in the smoking group compared with controls. No significant difference between the groups regarding the chewing pattern was observed.

- Table 2 shows the relationship between the presence of halitosis and oral changes in smokers. Fisher exact test 
372 Masticatory Changes as a Result of Oral Disorders in Smokers Rech et al.

Table 2 Relationship between the presence of halitosis and oral changes in smokers

\begin{tabular}{|c|c|c|c|c|c|c|}
\hline \multirow[b]{3}{*}{ Variable } & \multirow[b]{3}{*}{ Category } & \multicolumn{4}{|c|}{ Halitosis } & \\
\hline & & \multicolumn{2}{|c|}{ No } & \multicolumn{2}{|c|}{ Yes } & \\
\hline & & $n$ & $\%$ & $n$ & $\%$ & $p$ \\
\hline \multirow[t]{2}{*}{ Presence of cavities } & No & 11 & 68.8 & 6 & 75.0 & $>0.999$ (NS) \\
\hline & Yes & 5 & 31.3 & 2 & 25.0 & \\
\hline \multirow[t]{2}{*}{ Periodontal problems } & No & 10 & 62.5 & 1 & 12.5 & $0.033^{\mathrm{a}}$ \\
\hline & Yes & 6 & 37.5 & 7 & 87.5 & \\
\hline
\end{tabular}

Abbreviation: NS, not significant.

asignificant at $p \leq 0.05$.

showed a positive association between this variable and the presence of periodontal problems. - Table 3 shows the relationship between the total number of teeth and food crushing pattern in smokers. From the results of the ANOVA, it appears that the reduction of the total number of teeth was related to crushing food with the tongue.

In comparison between the duration of smoking and the study variables, dividing the sample between smokers with consumption of $<20$ and $\geq 21$ years, Fisher exact test showed the consumption of tobacco for 20 years or more was associated with the presence of halitosis and periodontal problems, as demonstrated in - Table 4 . Nevertheless, the appearance of any of these variables was associated with the quantity of cigarettes consumed per day $(p>0.05)$.

- Table 5 shows the comparison between the dental class in the right side and chewing characteristics in smokers. Fisher exact test showed that the speed of chewing was adequate when combined with the presence of class I, increased when associated with class II subdivision I, and decreased in class III. Furthermore, no relationship was observed between the occlusion of the right side class and chewing pattern. - Table $\mathbf{6}$, analyzing the occlusal class in left side, shows that chewing speed was adequate for individuals with class I, whereas individuals with class III had decreased speed. Nevertheless, the unilateral right masticatory pattern was associated with class I and simultaneous bilateral pattern with class III.

Table 3 Relationship between the total number of teeth and standard grinding food in smokers

\begin{tabular}{|l|l|l|l|l|}
\hline & \multicolumn{3}{|l|}{$\begin{array}{l}\text { Total number of } \\
\text { teeth }\end{array}$} & \\
\hline Crushing food & $n$ & Average & $\begin{array}{l}\text { Standard } \\
\text { deviation }\end{array}$ & $p$ \\
\hline Posterior teeth & 13 & 28.2 & 0.6 & $<0.001^{\mathrm{a}}$ \\
\hline Anterior teeth & 7 & 26.0 & 1.6 & \\
\hline With tongue & 4 & 17.3 & 2.9 & \\
\hline
\end{tabular}

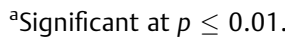

\section{Discussion}

According to the report of the World Health Organization, smoking is a risk factor for six of the eight leading causes of death worldwide. Tobacco kills prematurely, $\sim 15$ years earlier, about a third of its consumers. The consumption of tobacco has killed about five million people a year, and the forecast for 2030 shows a rise to more than eight million. ${ }^{12}$

Regarding oral health, the number of cigarettes consumed is correlated with increased incidence of oral diseases in combination with other risk factors. ${ }^{13}$ In Brazil, we found a high prevalence of tooth loss, affecting mostly males above 56 years old. The posterior teeth are most commonly affected, with caries the main cause, ${ }^{14}$ which is significantly associated with an increased risk of tooth loss in both genders. ${ }^{15}$ Smoking contributes to infection, inflammation, and destruction of teeth, beyond increased prevalence of periodontal disease caused by the formation of bacterial plaque, which accumulates and adheres to the tooth surface, resulting in local tissue destruction and tooth loss. ${ }^{16,17}$ Thinking about the function of the system, it is known that tooth loss will impact the pattern of occlusion and consequently affect the stomatognathic functions. Thus, the findings presented in this study agree with the data in the literature demonstrating higher oral alterations in smokers.

In addition to these structural changes, halitosis is increased in the smoker population. Halitosis is a change in oral odor of various origins. An unpleasant odor is caused by the emission of compounds that form inside the mouth and other parts of the body, eventually eliminated with the breath. ${ }^{18}$ Cigarette smoking is a major causative agent, because the substances ingested through smoking are expelled during exhalation. ${ }^{19}$ Smoking also results in pulp changes, influencing the physiology, metabolism, and alterations in connective tissue. Furthermore, this alteration interferes in the repair mechanisms of injuries, both locally and systemically. Moreover, dentin permeability, associated with smoking, enhances the predisposition to pulp changes. ${ }^{20}$ Therefore, the halitosis not only results from exhaled substances, but the periodontal changes also contribute.

Caries is the primary cause of tooth loss. It is known that caries increases the risk for tooth loss when associated with other disorders, such as periodontal disease. Deleterious oral habits also aggravate those losses, in particular smoking, 
Table 4 Comparison between groups regarding time and amount of smoking and oral characteristics

\begin{tabular}{|c|c|c|c|c|c|c|c|c|c|c|c|}
\hline \multirow[b]{3}{*}{ Variable } & \multirow[b]{3}{*}{ Category } & \multicolumn{4}{|c|}{ Time smoking } & & \multicolumn{4}{|c|}{ Cigarettes per day } & \\
\hline & & \multicolumn{2}{|c|}{$<20$} & \multicolumn{2}{|c|}{$\geq 29$} & \multirow[b]{2}{*}{ p } & \multicolumn{2}{|c|}{$<20$} & \multicolumn{2}{|c|}{$\geq 20$} & \\
\hline & & $n$ & $\%$ & $n$ & $\%$ & & $n$ & $\%$ & $n$ & $\%$ & $p$ \\
\hline \multirow[t]{2}{*}{ Halitosis } & No & 11 & 100.0 & 5 & 38.5 & \multirow[t]{2}{*}{$0.002^{\mathrm{a}}$} & 10 & 62.5 & 6 & 75 & \multirow[t]{2}{*}{0.667 (NS) } \\
\hline & Yes & - & - & 8 & 61.5 & & 6 & 37.5 & 2 & 25 & \\
\hline \multirow[t]{2}{*}{ Presence of caries } & No & 8 & 72.7 & 9 & 69.2 & \multirow[t]{2}{*}{$>0.999$ (NS) } & 12 & 75 & 5 & 62.5 & \multirow[t]{2}{*}{0.647 (NS) } \\
\hline & Yes & 3 & 27.3 & 4 & 30.8 & & 4 & 25 & 3 & 37.5 & \\
\hline \multirow[t]{2}{*}{ Periodontal problems } & No & 8 & 72.7 & 3 & 23.1 & \multirow[t]{2}{*}{$0.03^{b}$} & 6 & 37.5 & 5 & 62.5 & \multirow[t]{2}{*}{0.390 (NS) } \\
\hline & Yes & 3 & 27.3 & 10 & 76.9 & & 10 & 62.5 & 3 & 37.5 & \\
\hline
\end{tabular}

Abbreviation: NS, not significant.

${ }^{\mathrm{a}}$ Significant at $p \leq 0.01$.

bSignificant at $p \leq 0.05$.

Table 5 Comparison between dental class of the right side and mastication characteristics of smokers

\begin{tabular}{|c|c|c|c|c|c|c|c|c|c|c|}
\hline \multirow[b]{3}{*}{ Variable } & \multirow[b]{3}{*}{ Category } & \multicolumn{8}{|c|}{ Class of right side } & \multirow[b]{3}{*}{$p$} \\
\hline & & \multicolumn{2}{|c|}{ Class I } & \multicolumn{2}{|c|}{ Class III } & \multicolumn{2}{|c|}{ Class II/I } & \multicolumn{2}{|c|}{ Class II/II } & \\
\hline & & $n$ & $\%$ & $n$ & $\%$ & $n$ & $\%$ & $n$ & $\%$ & \\
\hline \multirow[t]{3}{*}{ Chewing speed } & Adequate & 10 & 83.3 & - & - & 1 & 33.3 & 2 & 50.0 & $0.002^{\mathrm{a}}$ \\
\hline & Increased & - & - & - & - & 1 & 33.3 & - & - & \\
\hline & Decreased & 2 & 16.7 & 5 & 100.0 & 1 & 33.3 & 2 & 50.0 & \\
\hline \multirow[t]{4}{*}{ Chewing pattern } & Bilateral alternating & 6 & 50.0 & 1 & 20.0 & 1 & 33.3 & 1 & 25.0 & 0.121 (NS) \\
\hline & Unilateral right & 2 & 16.7 & 1 & 20.0 & 1 & 33.3 & 2 & 50.0 & \\
\hline & Unilateral left & 4 & 33.3 & - & - & - & - & - & - & \\
\hline & Simultaneous bilateral & - & - & 3 & 60.0 & 1 & 33.3 & 1 & 25.0 & \\
\hline
\end{tabular}

Abbreviation: NS, not significant.

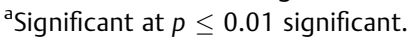

Table 6 Comparison between dental class of the left side and mastication characteristics of smokers

\begin{tabular}{|c|c|c|c|c|c|c|c|c|c|c|}
\hline \multirow[b]{3}{*}{ Variable } & \multirow[b]{3}{*}{ Category } & \multicolumn{8}{|c|}{ Class of left side } & \multirow[b]{3}{*}{$p$} \\
\hline & & \multicolumn{2}{|c|}{ Class I } & \multicolumn{2}{|c|}{ Class III } & \multicolumn{2}{|c|}{ Class II/I } & \multicolumn{2}{|c|}{ Class II/II } & \\
\hline & & $n$ & $\%$ & $n$ & $\%$ & $n$ & $\%$ & $n$ & $\%$ & \\
\hline \multirow[t]{3}{*}{ Chewing speed } & Adequate & 12 & 75.0 & - & - & - & - & 1 & 50 & \multirow[t]{3}{*}{$0.001^{\mathrm{a}}$} \\
\hline & Increased & - & - & - & - & 1 & 50 & - & - & \\
\hline & Decreased & 4 & 25.0 & 4 & 100.0 & 1 & 50 & 1 & 50 & \\
\hline \multirow[t]{4}{*}{ Chewing pattern } & Bilateral alternating & 6 & 37.5 & 1 & 25.0 & 1 & 50 & 1 & 50 & $0.011^{\mathrm{b}}$ \\
\hline & Unilateral right & 6 & 37.5 & - & - & - & - & - & - & \\
\hline & Unilateral left & 4 & 25.0 & - & - & - & - & - & - & \\
\hline & Simultaneous bilateral & - & - & 3 & 75.0 & 1 & 50 & 1 & 50 & \\
\hline
\end{tabular}

Abbreviation: NS, not significant.

asignificant at $p \leq 0.01$.

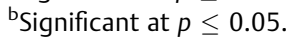

which results in higher rates of caries and therefore more tooth loss in smokers. ${ }^{15}$ This dynamic would explain the greater incidence of halitosis and caries found in the group of smokers.
The loss of a single tooth can impact the process of mastication. Absence of dental elements causes difficulties and pain during the chewing process. ${ }^{1}$ In addition to the losses in the process of mastication, these changes can impact 
the social and personal relationship of these individuals. ${ }^{21}$ Individuals with complete dentition have effective chewing ability, almost $100 \%$ in their functional capacity; in cases with tooth loss, this ability can be reduced to $70 \%{ }^{22}$ Thus, chewing ability among smokers is fundamentally conditioned by tooth loss, the high rates of edentulism, and the high prevalence of caries and periodontal diseases, generating inconsistent chewing pattern. ${ }^{23}$

Masticatory changes resulting from tooth loss can be explained due to the modification of dental occlusion. A major impact of tooth loss is related to the reduction in dental occlusion area, causing changes in normal occlusal relationships generating reduction in capacity of cutting and grinding food. The malocclusions cause impediments and generate malfunctions and imbalances on other elements within the masticatory system, which, in most cases, are hardly compensated. The malocclusions cause irregular chewing movements, with limitation of movement of vertical closure occurring before the maximum intercuspal. ${ }^{24}$

In the masticatory process, the tongue, in coordination with the cheeks, positions the food between the occlusal surfaces of posterior teeth (premolars and molars) that grind food, ${ }^{25}$ but this research shows that smokers used the tongue to crush food in tooth absence, as shown in - Table 3, also resulting in a reduced masticatory speed. Unlike the findings in the literature claiming that the inadequacy of the chewing time is due to a bad habit of the general population, ${ }^{1}$ it can be inferred that the chewing time in this specific group is related to the inadequate food crushing pattern with the tongue.

Although the dose-response relationship between length of tobacco use and onset of diseases related to its use does not always take a linear form, longer time and greater amount of tobacco consumed in general are associated with the development, increase, or aggravation in changes and diseases arising from the effects of tobacco. Tobacco use has devastating effects on health and longevity, affecting practically all organs and functions. ${ }^{26}$ The present study confirms that consumption of tobacco for 20 years or more is associated with the presence of halitosis and periodontal problems, and the appearance of none of these variables is associated with the amount of tobacco consumed per day.

Unilateral chewing is an adaptation mechanism to ensure minimal trauma to the periodontal, teeth, and joints. Only structures of the working side are stimulated, thus preventing the physiologic abrasion of tooth cusps of the idle side, allowing occlusal interferences and also favoring the installation of bacterial plaque, caries, and periodontal disorders. ${ }^{24}$ Over the years, unilateral chewing can result in an asymmetric growth of the face. ${ }^{27}$

Moreover, these changes influence the effectiveness of the masticatory system, including the time and number of chewing hits performed. Individuals who do not have dental deformities or features of class II tend to maintain a more uniform chewing pattern in the number of hits and chewing time, but the same does not occur with class III subjects, whose mastication speed is reduced. ${ }^{25}$ In class III individuals, who have malocclusion with mandibular prognathism, movements are predominantly vertical and have little or no lateral component and are not considered an efficient masticatory pattern, showing no rhythmic characteristics. ${ }^{24}$ Based on these aspects, the occlusal changes predispose to more chewing changes, such as changes in time, speed, and chewing pattern, even if the dental anomalies occur only in one occlusal side, as demonstrated in this study.

\section{Conclusion}

We verified that smoking is correlated with oral disorders, which are risk factors for tooth loss and masticatory changes.

Speech-language pathology intervention with smokers is initially prevention; however, the consequences caused by smoking make smokers future patients because of the imbalance in the stomatognathic system. More studies should be done to raise awareness in the population about the damage caused by smoking and also to standardize the findings in this population.

\section{References}

1 Jorge TM, Bassi AKZ, Yarid SD, et al. Relação entre perdas dentárias e queixas de mastigação, deglutição e fala em indivíduos adultos. Rev CEFAC 2009;11(Suppl 13):391-397

2 Moyers RE. Ortodontia. $4^{\underline{a}}$ ed. Rio de Janeiro, Brazil: GuanabaraKoogan; 1991

3 Ahlgren J. Mechanism of mastication. Acta Odontol Scand 1966; 24(44):1-109

4 Angle EH. Malocclusion of the Teeth. 7th ed. Philadelphia, PA: SS White Dental Mfg Co; 1907

5 Al-Bayaty FH, Wahid NA, Bulgiba AM. Tooth mortality in smokers and nonsmokers in a selected population in Sana'a, Yemen. J Periodontal Res 2008;43(1):9-13

6 Johnson NW, Bain CA; EU-Working Group on Tobacco and Oral Health. Tobacco and oral disease. Br Dent J 2000;189(4):200-206

7 Instituto Nacional de Câncer-INCA. Ministério da Saúde-Brasil. Convenção-Quadro para o Controle do Tabaco. 2011

8 Freitas AR, Mapengo MAA, Moura PG, et al. Restrição ao uso de tabaco e a prevenção do câncer bucal. Arq. Ciênc Saúde 2010; 17(1):54-57

9 Silva JBP, Sobrinho JÁ, Boraks S, Galvão MAL, Rapoport A. Alterações citológicas da semi-mucosa do lábio inferior em pacientes expostos às radiações solares e o uso do fumo. Rev Bras Otorrinolaringol 2000;66(5):494-498

10 Lima CF. Avaliação quantitativa de micronúcleos na citologia esfoliativa da mucosa bucal de pacientes dependentes químicos [dissertação]. São José dos Campos, Brazil: Universidade Estadual Paulista "Júlio de Mesquita Filho"; 2007

11 Braga FL, Meneguzzi RD, Paiva RL, Rados PV. Avaliação citopatólogica da mucosa bucal de fumantes e não-fumantes. Rev Odonto Ciênc 2004;19(44):157-163

12 Organização Mundial de Saúde. Relatório da OMS sobre a Epidemia global de tabagismo. 2008

13 Kinane D. Doença periodontal, fator de risco para as doenças gerais. Jornal da Assoc Brás Odontol Prev 1999;9(1):11

14 Carneiro VFA, Rodrigues DCV, Ribeiro AAM, Rocha RACP, Farias ABL, Cavalcanti AL. Ocorrência de Perda Dentária entre os Usuários da Estratégia de Saúde da Família do Município de Campina Grande-R bras ci Saúde. 2010;16(2):137-142

15 Nakayama Y, Mori M. The relationship between number of natural teeth and oral health behavior in adult Japanese people. J Natl Inst Public Health 2012;61(4): 
16 Leal LMSJO. Efeitos Nocivos do Fumo do Tabaco sobre o aparelho bucal [dissertação]. Covilhã, Portugal: Universidade da Beira do Interior; 2011

17 Morita M, Wang HL. Association between oral malodor and adult periodontitis: a review. J Clin Periodontol 2001;28(9):813-819

18 Bianchini MA, Andriani FN, Magini RS, Zimmermann GS. A periodontia e a etiologia das halitoses. Revista Ciências da Saúde 2007; 26(1):16-23

19 Domingos PAS, Abreu AC, Dantas AAR, Oliveira ALBM. Halitose: limitando a qualidade de vida. Rev Odontol Univ Cid São Paulo 2011;23(2):171-181

20 Ribeiro ILA, Veloso HHP. Influência do Tabagismo nas Alterações Pulpares. Odontol Bras Central 2012;21(58)

21 Loesche WJ, Kazor C. Microbiology and treatment of halitosis. Periodontol 2000 2002;28:256-279
22 Beck J, Hunt RJ. Oral health status of institutionalized elderly and hand capped. J Dent Educ 1985;49(6):407-425

23 Dias-da-Costa JS, Galli E, Oliveira EA, et al. Prevalência de capacidade mastigatória associados em idosos brasileiros. Cad Saude Publica 2010;26(1):79-88

24 Picinato-Pirola MNC, Mello-Filho FV, Trawitzki LVV. Tempo e golpes mastigatórios nas diferentes deformidades dentofaciais. Soc Bras Fonoaudiol 2012;24(2):130-133

25 Duarte LIM. Relação entre maloclusão e mastigação [dissertação]. Londrina, Brazil: CEFAC; 2000

26 Nunes E. Consumo de tabaco. Efeitos na Saúde. Rev Port Clin 2006; 22:225-244

27 Fernandes RC. Oclusão dentária e mastigação. A relação entre forma e função [dissertação]. Itajaí, Brazil: CEFAC; 2001 